Case Reports
in Dermatology
Case Rep Dermatol 2021;13:171-175

DOI: $10.1159 / 000513474$

Published online: March 18, 2021
(C) 2021 The Author(s)

Published by S. Karger AG, Basel www.karger.com/cde

This article is licensed under the Creative Commons Attribution-NonCommercial 4.0 International License (CC BY-NC) (http://www.karger.com/Services/OpenAccessLicense). Usage and distribution for commercial purposes requires written permission.

\title{
A Case of Epidermal Cyst with Underlying Lipoma on the Back: A Rare Presentation
}

\author{
Yuichi Kurihara $^{a, b} \quad$ Koji Kawamura ${ }^{a, b} \quad$ Masutaka Furue $^{b}$ \\ ${ }^{a}$ Department of Dermatology, Karatsu Red Cross Hospital, Karatsu, Japan; ${ }^{b}$ Department of \\ Dermatology, Graduate School of Medical Sciences, Kyushu University, Fukuoka, Japan
}

\section{Keywords}

Epidermal cyst · Lipoma · Coexistence

\begin{abstract}
The coexistence of epidermal cysts and lipomas at the same site is extremely rare, although epidermal cysts and lipomas are both common benign skin tumors. We present a rare case of an epidermal cyst with underlying lipoma on the back. This case report may simply be a result of coincidence, but the possibility of underlying subcutaneous tumors should be considered before epidermal cyst surgery.

\section{Introduction}

Epidermal cysts and lipomas are both common benign skin tumors [1, 2]. However, to the best of our knowledge, there are no reports describing the coexistence of epidermal cysts and lipomas at the same site. In this report, we present a case of an epidermal cyst with underlying lipoma on the back. 


\section{Case Reports in Dermatology}

\begin{tabular}{l|l}
\hline Case Rep Dermatol 2021;13:171-175 \\
\hline DOI: 10.1159/000513474 & $\begin{array}{l}\text { (c) 2021 The Author(s). Published by S. Karger AG, Basel } \\
\text { www.karger.com/cde }\end{array}$ \\
\hline
\end{tabular}

Kurihara et al.: A Case of Epidermal Cyst with Underlying Lipoma on the Back: A Rare Presentation

\section{Case Presentation}

A 75-year-old man visited our department complaining of an elastic hard, well-demarcated, $1.4 \times 1.2 \mathrm{~cm}$, dome-shaped nodule on the upper back (Fig. 1). Taken together with sonographic findings, the round-to-oval shape, posterior echo enhancement, and lateral shadowing (Fig. 2), the preoperative diagnosis was determined as epidermal cyst, and excision was performed under local anesthesia. However, a $5.8 \times 4.5 \mathrm{~cm}$ subcutaneous tumor remained on the right upper back after the operation (Fig. 3). Reviewing the chest CT screen for signs of COVID-19 revealed a subcutaneous lesion beneath the epidermal cyst with adipose tissue signal (Fig. 4). The remaining lesion was removed and the pathological diagnosis was consistent with lipoma.

\section{Discussion}

Epidermal cysts are the most common benign lesions [3], with obstruction of hair follicles and traumatic or surgical implantation of epidermis in the nonfollicular area resulting in their formation [1].

Similarly, lipomas are also common mesenchymal, slow-growing benign tumors [4]. The etiology of lipomas is unclear, although genetic background and mechanical trauma have been suggested for their pathogenesis [2].

In the current case, the coexistence of epidermal cyst and underlying lipoma may simply be a coincidence; however, repetitive mechanical stress on the back might have resulted in both epidermal and subcutaneous tumors.

For this case, two dermatologists had overlooked the underlying lipoma. While ultrasonic examination was evaluated by a skilled laboratory technician and chest CT image interpretation was performed by a specialist in radiology, the lesion in the subcutaneous area went unnoticed before removal of the epidermal cyst, likely due to cognitive bias. This case is a rare presentation, but nonetheless demonstrates the prudence of considering the possibility of an underlying subcutaneous tumor prior to epidermal cyst removal.

\section{Statement of Ethics}

The authors state that the patient has given written informed consent to publish this case report. The study was conducted ethically in accordance with the World Medical Association Declaration of Helsinki. This paper is exempt from ethical committee approval, since we present a single case study, not an experimental or an observational study.

\section{Conflict of Interest Statement}

The authors have no conflicts of interest to declare.

\section{Karger'}




\section{Case Reports in Dermatology}

\begin{tabular}{l|l}
\hline Case Rep Dermatol 2021;13:171-175 \\
\hline DOI: 10.1159/000513474 & $\begin{array}{l}\text { c 2021 The Author(s). Published by S. Karger AG, Basel } \\
\text { www.karger.com/cde }\end{array}$ \\
\hline
\end{tabular}

Kurihara et al.: A Case of Epidermal Cyst with Underlying Lipoma on the Back: A Rare Presentation

\section{Funding Sources}

None of the authors received any financial support for the present study.

\section{Author Contributions}

Y.K. was involved in the conception of the work and drafted the work. K.K. was involved in the acquisition of data. M.F. was involved in the design of the work and the analysis of data. All authors have read and approved the manuscript.

\section{References}

1 Yuan WH, Hsu HC, Lai YC, Chou YH, Li AF. Differences in sonographic features of ruptured and unruptured epidermal cysts. J Ultrasound Med. 2012 Feb;31(2):265-72.

2 Aust MC, Spies M, Kall S, Jokuszies A, Gohritz A, Vogt P. Posttraumatic lipoma: fact or fiction? Skinmed. 2007 Nov-Dec;6(6):266-70.

3 Fisher AR, Mason PH, Wagenhals KS. Ruptured plantar epidermal inclusion cyst. AJR Am J Roentgenol. 1998 Dec;171(6):1709-10.

4 Derin AT, Yaprak N. Lipomas: Review and evaluation of the literature. Clin Surg. 2017;2:1615.

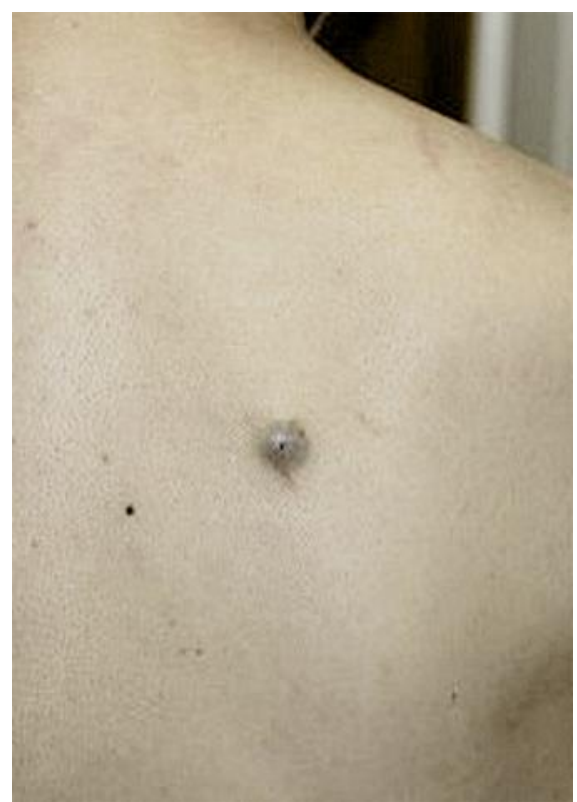

Fig. 1. Well-defined and dome-shaped lesions on the upper back.

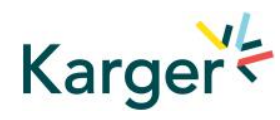



www.karger.com/cde

Kurihara et al.: A Case of Epidermal Cyst with Underlying Lipoma on the Back: A Rare Presentation

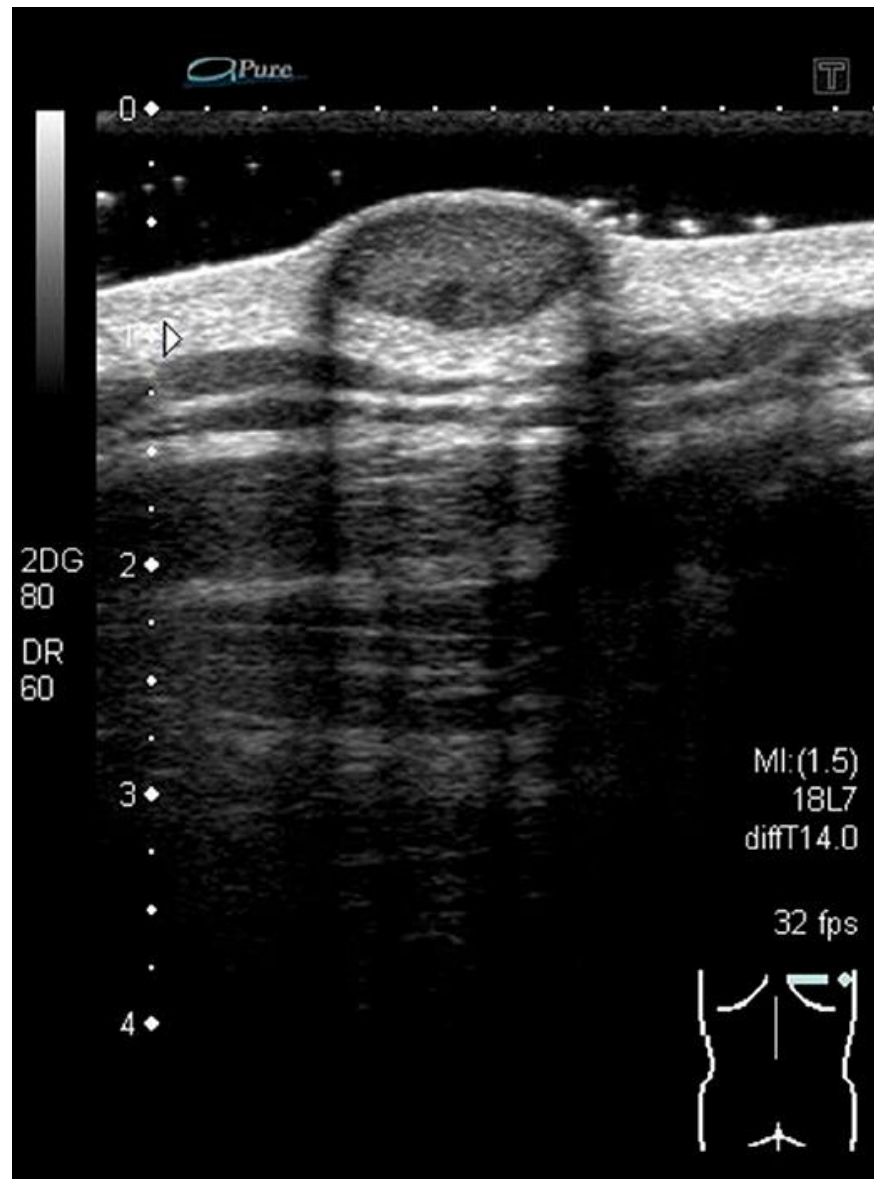

Fig. 2. Sonographic findings of lesions on the upper back. 


\section{Case Reports in Dermatology}

Case Rep Dermatol 2021;13:171-175

DOI: $10.1159 / 000513474$

(c) 2021 The Author(s). Published by S. Karger AG, Basel www.karger.com/cde

Kurihara et al.: A Case of Epidermal Cyst with Underlying Lipoma on the Back: A Rare Presentation

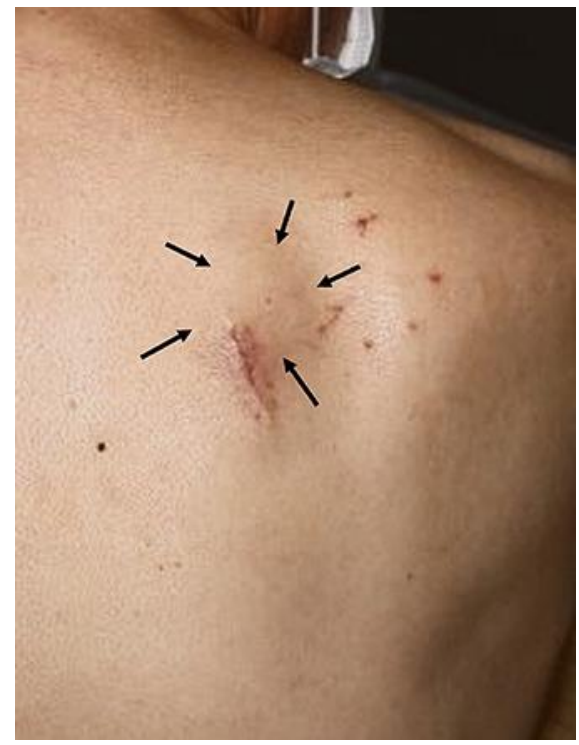

Fig. 3. Remaining lesion on the right upper back.

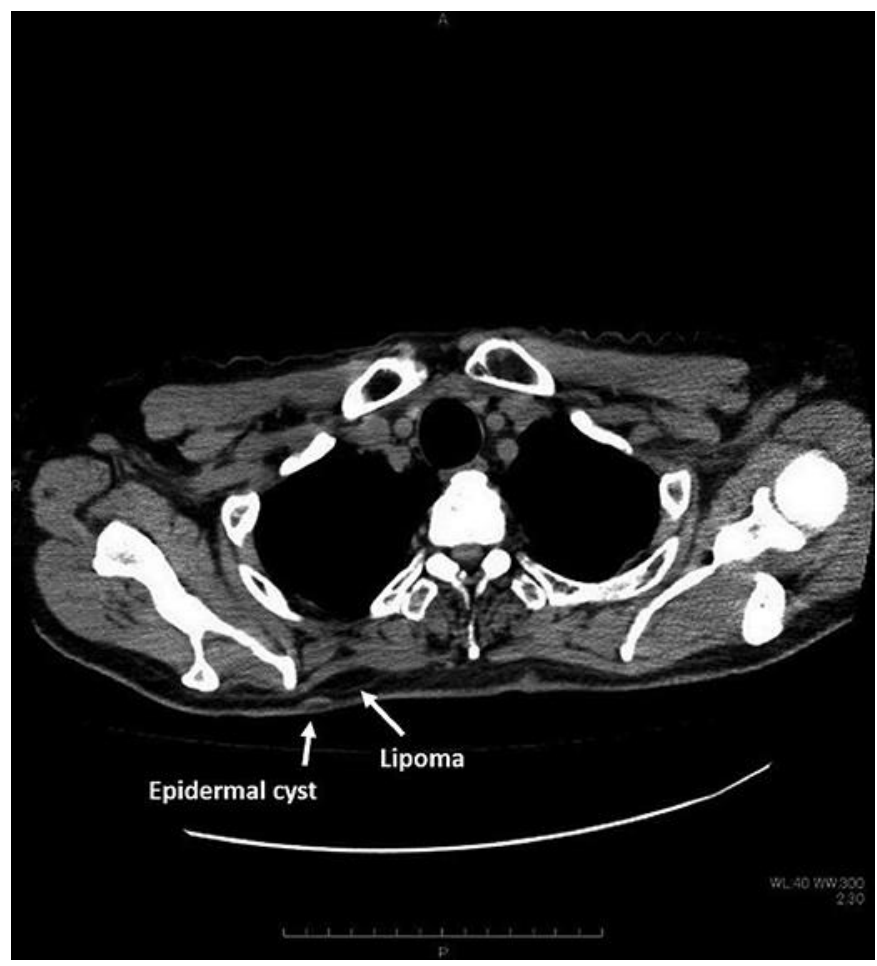

Fig. 4. Chest CT image before removal of epidermal cyst.

\section{Karger's}

